\title{
Fungi ecological niches of the genus Fusarium Link.
}

\author{
Irina Vorob'eva ${ }^{1 *}$, and Elena Toropova ${ }^{2}$ \\ ${ }^{1}$ Central Siberian Botanical Garden of the Siberian Branch of the Russian Academy of Sciences, \\ 630090, Novosibirsk, Russian Federation. \\ ${ }^{2}$ Novosibirsk State Agrarian University, 630070, Novosibirsk, Russian Federation.
}

\begin{abstract}
Climatic variations and modern agricultural technologies change the fungi distribution area ofthe genus Fusarium Link., and lead to their dominance in pathocomplexes. The parasitic activity of fusarium fungi and localization of their ecological niches is determined by the activity of constantly expanding environmental and anthropogenic drivers. The fundamental niches of Fusarium pathogens are characterized by complexity and multidimensionality. Realized ecological niches change in space and time at the ontogenesis different stages of pathogenic micromycetes; the same species shows high heterogeneity in implementing its fundamental niche depending on environmental factors and the host plant species. The overlap level of ecological niches and interspecific relationships largely determine the species composition of the pathogenic complex of adiscrete phytocenosis.
\end{abstract}

\section{Introduction}

Fungi of the genus Fusarium Link. are permanent soil inhabitants and cause widespread and harmful diseases of agricultural and wild plant species [1]. A number of species is particularly harmful, including $F$. oxysporum Schlecht. - a causative agent of tracheomycotic wilt and root rot of many plant species, as well producers of dangerous mycotoxins as F. graminearum Schwabe, F. culmorum (W.G. Sm.) Sacc., F. moniliforme Sheld., F. solani (Mart.) App. et Wr., F. sporotrichioides Sherb., etc. The fusarium fungi habitat changed significantly in the 21 st century due to climatic fluctuations and agricultural technology changes [2, 3, 4]. In 2007-2018, the population of Fusarium spp. on underground organs of grain crops 2.5-8 times exceeded the amount of previously dominant Bipolaris sorokiniana Sacc. Shoem. The highest frequency of fungi occurrence on wheat and barley underground organs was observed for F. equiseti (Corda) Sacc., F. poae (Pk.) $W r$., F.oxysporum, F. solani, F. sporotrichioides and F. subglutinans (Wollenweber \& Reinking) Nelson, Toussoun \& Marasas [3]. Among the factors ensuring the Fusarum dominance in the root rot pathocomplex all over the world, it should be noted the increased

* Corresponding author: vorobig@ngs.ru 
climate contrast and aridity, minimized soil cultivation, annual seed treatment of agricultural crops with triazole preparations, reduced soil suppression to fusarium fungi, soil contamination with weed seeds $[3,5,6]$. Phytopathogenic fungi of the genus Fusarium affect both the plant underground organs and vascular bundles, and aboveground vegetative and generative organs, which infection can occur along tubules or with airborne droplets [1, 7]. The parasitic activity of phytopathogens and localization of their ecological niches are determined by environmental and anthropogenic drivers, their list is constantly expanding $[3,8,9]$.

In this regard, a detailed analysis of the structure of fundamental ecological niches and mechanisms of their implementation by fungi of the genus Fusarium has become highly relevant.

\section{Materials and Methods}

To analyze the ecological niches of pathogenic micromycetes, we have proposed an evolutionary-ecological classification according to which the phytopathogen ecological niches can be divided into specific and non-specific ones. Specific ecological niches are those determining the life cycle continuity of pathogenic micromycetes, ensuring their reproduction (tactics $\mathrm{P}$ ), survival (tactics $\mathrm{B}$ ), and trophic relations (tactics $\mathrm{T}$ ) in agrarian and natural ecosystems. Non-specific niches are random, formed under the influence of environmental and anthropogenic factors in agrarian and (or) natural ecosystems. Specific ecological niches, in turn, are divided into first and second order niches, taking into account the allocation of pathogenic parasites to appropriate habitats for their vital functions. The first order niches are those of pathogenic micromycetes in the body of the host plants servicing for nutrition and reproduction; and the second order niches are environmental ones ensuring their survival (circulation) in time and space. To quantify the size of ecological niches, they are divided into the main ones determined the mass functioning of pathogenic micromycetes in agrarian and (or) natural ecosystems, and additional ones that are formed individually [10].

\section{Results and Discussion}

Species of the genus Fusarium realize specific primary and additional ecological niches of the first order on the plant organs during the growing season, providing trophic and reproduction functions of micromycetes in agrarian and natural ecosystems. Micromycetes are adapted to survive in time from year to year mainly in soil, on (in) plant residues, and seeds in a form of specific resting structures (sclerotia, chlamydospores, dormant mycelium), while they form the main and additional ecological niches of the second order to ensure survival populations in agrarian and (or) natural ecosystems. The composition of the main and additional ecological niches for survival in time, as well as the forms of resting structures, can vary on different host plants. This is due to the biological characteristics of plants, their cultivation technology, and soil-climatic conditions of their distribution area.

Accounting the knowledge state on pathogenic micromycetes, we paid special attention to the analysis of ecological niches of $F$. oxysporum and some other species parasitizing in a single pathogenic complex on plants. A peculiarity of $F$. oxysporum is specialized form presence on a number of agrarian cultures, which evidences its evolutionary advancement and plasticity character for the genus other representatives as well [11]. The literature describes more than 100 forms of $F$. oxysporum parasitizing on more than 150 plant species $[1,7]$. 
A micromycete realizes specific ecological niches of the first (for nutrition and reproduction) and second (for survival in time) orders from year to year (soil, infected plant residues, seeds, roots, tubers, etc.) on all cultures. It is possible that the phytopathogen forms and implements non-specific ecological niches when injuring agricultural products with harvesting equipment.

Let's consider the fungi specific ecological niches on different crops during the growing season (Table 1).

Table 1. Specific ecological niches of F. oxysporum on plant organs during the growing season (firstorder niches

\begin{tabular}{|c|c|c|c|c|}
\hline \multirow{2}{*}{ Culture } & \multicolumn{2}{|c|}{ Niche on (in) plant organs } & \multicolumn{2}{|c|}{ Propagative structure } \\
\hline & main & additional & main & additional \\
\hline Spring wheat & $\begin{array}{l}\text { Underground } \\
\text { organs (root } \\
\text { system, epicotyl, } \\
\text { spear base) }\end{array}$ & $\begin{array}{l}\text { Vascular- } \\
\text { conducting } \\
\text { system, } \\
\text { aboveground } \\
\text { organs (leaves, } \\
\text { ear, caryopsis) }\end{array}$ & $\begin{array}{l}\text { Air mycelium, } \\
\text { micro-and } \\
\text { macroconidia }\end{array}$ & $\begin{array}{l}\text { Sporodochia, } \\
\text { pionnotes, } \\
\text { macroconodia }\end{array}$ \\
\hline Flax & $\begin{array}{l}\text { Vascular- } \\
\text { conducting } \\
\text { system, germinal } \\
\text { organs of the, } \\
\text { stems, leaves, } \\
\text { fruitcase }\end{array}$ & $-*$ & $\begin{array}{l}\text { Air mycelium, } \\
\text { micro-and } \\
\text { macroconidia }\end{array}$ & - \\
\hline Cabbage & $\begin{array}{l}\text { Vascular- } \\
\text { conducting } \\
\text { system, roots, } \\
\text { leaves of seedlings } \\
\text { and adult plants }\end{array}$ & Head upper part & $\begin{array}{l}\text { Air mycelium, } \\
\text { micro-and } \\
\text { macroconidia }\end{array}$ & - \\
\hline Potato & $\begin{array}{l}\text { Roots, tubers, } \\
\text { stem basal part, } \\
\text { stolons }\end{array}$ & $\begin{array}{l}\text { Vascular- } \\
\text { conducting system }\end{array}$ & Air mycelium & $\begin{array}{l}\text { Sporodochia, } \\
\text { pionnotes, } \\
\text { macroconodia }\end{array}$ \\
\hline Clover & $\begin{array}{l}\text { Vascular- } \\
\text { conducting } \\
\text { system, germinal } \\
\text { organs, roots }\end{array}$ & - & $\begin{array}{l}\text { Air mycelium, } \\
\text { micro-and } \\
\text { macroconidia }\end{array}$ & $\begin{array}{l}\text { Спородохии, } \\
\text { macroconodia }\end{array}$ \\
\hline Soya & $\begin{array}{l}\text { Vascular- } \\
\text { conducting } \\
\text { system, seedling } \\
\text { germinal organs, } \\
\text { roots, stems, } \\
\text { beans, seeds }\end{array}$ & - & $\begin{array}{l}\text { Air mycelium, } \\
\text { micro-and } \\
\text { macroconidia }\end{array}$ & $\begin{array}{l}\text { Pionnotes, } \\
\text { macroconodia }\end{array}$ \\
\hline Rice & $\begin{array}{l}\text { Vascular- } \\
\text { conducting } \\
\text { system, seedling } \\
\text { germinal organs, } \\
\text { roots, stem nodes }\end{array}$ & $\begin{array}{l}\text { Leaf tops in dry } \\
\text { weather, panicle } \\
\text { branches }\end{array}$ & $\begin{array}{l}\text { Air mycelium, } \\
\text { microconidia }\end{array}$ & Macroconodia \\
\hline
\end{tabular}

Note: * - no information available

F. oxysporum main ecological niche of the first order is the vascular conducting system of the plant underground (roots, tubers) and aboveground (stems) organs, resulting in a systemic infection of plants starting with the seed germination phase to the growing season end. The result of implementing the main fundamental niche of the first order - plant organs - tracheomycotic wilting of plants develops (flax, cabbage, clover, rice), which leads to their wilting and a sharp decrease in productivity, especially in case of moisture deficiency 
or humidity drops. F. oxysporum in the pathocomplex with the genus other representatives causes mainly root rot on other host species (spring wheat, potatoes), as its main niche of the first order is underground plant organs. The following regularity is observed on all plants: the earlier the phytopathogen realized an ecological niche during the growing season, the greater its size and disease harmfulness.

$F$. oxysporum forms micro- and macroconidia on the aerial mycelium during vegetation in the main ecological niche (the vascular conduction system of the underground organs of plants). They perform the function of the ecological niche expanding in space, and ensure affection of the plant aboveground organs. Aboveground organs, like ecological niches, may be of main and additional significances conditioned by plant systemic infection or (and) the airborne mechanism of phytopathogen transmission.

The structure of $F$. oxysporum main fundamental niche varies by plant species and undergoes changes influenced by the anthropogenic press. So, on spring wheat, the main specific ecological niche of the first order is primary and secondary roots, epicotyl, a stem base, on (in) which the fungus parasitizes together with other species of the genus $(F$. avenacium (Fr.) Sacc., F. poae, F moniliforme, F. sambucinum Fuck, F. solani, $F$. sporotrichioides, etc.) causing mostly root rots. In the $20^{\text {th }}$ century, researchers noted narrow ecological niches of the first order on primary roots, and wide ones - on secondary roots, which was related to Fusaria confinement to humid conditions. Similar patterns were revealed in the climatic zones: in humid zones (subtaiga foothills, northern forest-steppe) roots were more populated by Fusaria then in arid zones (southern forest-steppe). In addition, the high frequency of fusarium fungi occurrence in the subtaiga zone was due to the presence of sod-podzolic soils with an acidic reaction, but in taiga and forest-steppe due to lower radiation compared to the steppe zone [12]. Under a moderate population of zonal soils by fungi propagators of the genus Fusarium character for the studied period, the dry conditions of the late growing season caused the depression of first-order ecological niche widening on the plant aerial organs: the genus Fusarium species were marked on seeds of grain crops in 1.3 to $33.8 \%$ (average $8.9 \%$ ) of cases with a maximum in West Siberian taiga, subtaiga and foothills [7]. In the $21^{\text {st }}$ century, under changing spring wheat cultivation technologies, transition to minimizing tillage, and widespread apply of azole seed dressers, Fusarium fungi, including $F$. oxysporum, received an incentive to strengthen the implementation of ecological niches in all natural zones, due to soil compaction, its acidification, and relative stability of the genus micromycetes to azoles [3]. These factors provided the fusaria with advantages in realizing ecological niches in all underground organs of cereals expressed in their unconditional dominance on primary and secondary roots, as well as settling straw plant organs, where their share in pathogenic complexes reached $60-70 \%$ [13]. The fungi dominance of the genus Fusarium on the cereal underground organs led to their active expansion of ecological niches into plant aboveground, especially generative organs. In contrast to the above data, the prevalence of fusarium fungi on wheat seeds reached $70 \%$ or more. The following species of fungi of the genus Fusarium were systematically isolated in spring wheat seeds: F. acuminatum Ellis \& Everh., $F$. avenaceum, F. culmorum, $F$. equiseti, $F$. heterosporum Nees, F. incarnatum (Desm.) Sacc., F. oxysporum, F. poae, F. solani, F. sporotrichioides, etc. The overlap level of ecological niches and interspecific relationships largely determine the species composition of the pathogenic complex of discrete phytocenosis seeds [14]. In Siberia, regardless of the natural zone, the presence of $F$. graminearum, a main causative agent of spike fusariosis, has recently increased on grain crop seeds led to grain contamination with mycotoxins [15]. That is, we can state a significant expansion of the fusaria biological diversity under modern conditions, their propagation in all zones of growing cereal host plants. 
On soya, $F$. oxysporum in a pathocomplex with $F$. gibbosum App. et Wr. emend. Bilai, $F$. poae, and $F$. solani use the plant underground organs as an ecological niche, starting with the seed germination phase. Sprouts die, as a rule. After forming additional roots, the plants survive, however, developing nodules and crop yield decreases sharply. Fusarium species occupy in the total mycocenosis of soil phytopathogens during a seedling phase $51.5 \%$, flowering - bean seedlings $-44.5 \%$, ripening - $36.3 \%$, which confirms the data on germs and seedlings as the fungus main ecological niche at the early vegetation and its gradual narrowing (1.4 times) by the late growing season.

On flax, the causative agent of fusariosis (F. oxysporum $f$. Lini Bolley) uses seedlings and adult plants as a specific ecological niche in all regions. The niche expands in wet weather according to the scheme: underground organs $\rightarrow$ aboveground organs, thanks to the air-drop mechanism of micro- and macroconidium transmission at a wide temperature range $\left(10^{\circ} \ldots 37^{\circ} \mathrm{C}\right.$, optimum $\left.22^{\circ} \ldots 24^{\circ} \mathrm{C}\right)$. Micromycetes penetrate into the plant vascularconducting system causing their intoxication, wilting and premature death. Mass $F$. oxysporum $f$. lini settling takes place on flax bolls and seeds, the phytopathogen spreading reaches $17-24 \%$ on flax seeds, which corresponds to the level of strong epiphytotia. Generative organs often serve as a niche for the genus species complex: $F$. oxysporum $f$. lini, F. avenacium, F. equiseti, F. sporotrichioides, $F$. solani, etc., especially in humid weather [16].

On clover, the fusariosis causative agent ( $F$. oxysporum $f$. Trifolii Raillo) affects plants of all ages. The pathogen first implements an ecological niche on seedlings in the submucosal knee and root tip, then, under it expanding, it can cause death of plants even before they reach the soil surface. Basic and lateral roots become the phytopathogen main niche on plants of the second and third years of life. The plant wilt, when fungus biomass filled the root vessels (especially their upper part), and the stem base. The fungus ecological niche widening occurs with age led to the plant death, decrease in their productivity and life expectancy reduction from 3-4 to 2 years.

After the host plants die off, phytopathogens are forced to adapt to survival in the environment using different substrates as second-order ecological niches (Table 2).

Table 2. Specific ecological niches of $F$. oxysporum in the period of survival in time (from year to year) (second-order niches)

\begin{tabular}{|c|c|c|c|c|}
\hline \multirow{2}{*}{ Culture } & \multicolumn{2}{|c|}{ Niche for the survival in time } & \multicolumn{2}{|c|}{ Resting structure } \\
\hline & main & additional & main & additional \\
\hline Spring wheat & Soil, IPR & Seeds & Sclerotia, mycelium & Chlamydospores \\
\hline Flax & $\begin{array}{l}\text { Soil, IPR, } \\
\text { seeds }\end{array}$ & $-*$ & $\begin{array}{l}\text { Chlamydospores, } \\
\text { mycelium }\end{array}$ & Sclerotia \\
\hline Cabbage & Soil, IPR & - & $\begin{array}{l}\text { Sclerotia, } \\
\text { chlamydospores } \\
\text { mycelium }\end{array}$ & - \\
\hline Potato & $\begin{array}{l}\text { Soil, IPR, } \\
\text { tubers }\end{array}$ & - & $\begin{array}{l}\text { Mycelium, sclerotia, } \\
\text { chlamydospores }\end{array}$ & - \\
\hline Clover & Soil, IPR & - & $\begin{array}{l}\text { Sclerotia, } \\
\text { chlamydospores } \\
\text { mycelium }\end{array}$ & - \\
\hline Soya & $\begin{array}{l}\text { Soil, IPR, } \\
\text { seeds }\end{array}$ & & $\begin{array}{l}\text { Chlamydospores, } \\
\text { mycelium }\end{array}$ & Sclerotia \\
\hline Rice & $\begin{array}{l}\text { Soil, IPR, } \\
\text { seeds }\end{array}$ & - & Sclerotia, mycelium & Chlamydospores \\
\hline
\end{tabular}

Note: IPR-infected plant residues; * - no information available

For all examined plant species, the main ecological niche to implement B tactics (survival) from year to year (up to 5-15 years) is soil, infected plant residues, and seeds, in 
some cases. The latter are an additional niche for micromycete survival in time (up to 7 years) in the form of a dormant mycelium, providing the function of expanding ecological niches in space. When sowing soil pathogens with seeds, their ecological niche size expands as a result of forming in soil, first temporary, and then permanent epiphytotic foci. The survival function is performed by dormant mycelium, sclerotia, and chlamydospores, but their role varies in cultures. For example, in soya agrocenoses, chlamydospores, dormant mycelium, rarely sclerotia serve for $F$. oxysporum survival in time. However, another species, $F$. equiseti, parasitic on soybean in the pathocomplex with $F$. oxysporum, forms sclerotia profusely, increasing the micromycete infectious potential in soils, which is a result of the plant residues conservation and colonization by plant pathogens as well. Thus, a powerful potential of the genus Fusarium species is formed in soils after soya providing long-term dynamics of the ecological niche implementation during the growing season of host plants.

Besides specific ecological niches (main, additional), the fusariosis causative agents form non-specific ecological niches during the period of spread and survival in time. First of all, it's facilitated by anthropogenic activity. Soil cultivation tools move micromycetes from epiphytotic foci to healthy soils. Under airborne mechanism of pathogen transmission, such niches are expanded by insects, birds, who spread propagative structures at great distances from their reproduction source in a specific niche [17]. A similar function can be performed by any object moving through a plant population during the fungus conidia formation [18]. The examples evidence the possibility of forming non-specific ecological niches in agricultural and natural ecosystems, however, their quantitative assessment requires clarification in each specific case.

\section{Conclusion}

Thus, the evolutionary-ecological analysis of the ways to implement fundamental ecological niches by fusarium pathogens of agricultural plants shows their complexity and multi-dimensionality. The realized ecological niches of pathogenic micromycetes change in space and time at the ontogenesis different stages, and the same species shows high heterogeneity in realizing its fundamental niche depending on environmental factors and the host plant species.

\section{References}

1. A. V.I. Bilay, Fusaria (Naukova dumka, Kiev, 1977) In Russ.

2. M.M. Levitin, Agricult. Biol. 50, 641-647 (2015) In Russ.

3. E.Yu Toropova, M.P. Selyuk, O.A. Kazakova, Agrochem. 5, 73-82 (2018) In Russ.

4. A. Bernhoft, M. Torp, P.-E. Clasen, A.-K. Loes, A.B. Kristoffersen, Food Add. Contams A, 1-12 (2012)

5. G.R. Dixon, E.L. Tilston, Soil-borne pathogens and their interactions with the soil environment, in Soil Microbiology and Sustainable Crop Production (Springer Science, 2010)

6. F.M. Doohan, J. Brennan, B.M. Cooke, Eur. J. Pl. Pathol. 109, 755-768 (2003)

7. V.A. Chulkina, Root rot of cereals in Siberia (Nauka, Novosibirsk, 1985) In Russ.

8. T.Yu. Gagkaeva, O.P. Gavrilova, M.M. Levitin. Biosphere 6, 36-45 (2014) In Russ.

9. C.W. Bacon, I.E. Yates, Soil Biol. 9, 133-152 (2006)

10. I.G. Vorob'eva, E.Yu. Toropova, Cont. Probl, of Ecol, 12, 667-674 (2019) 
11. G.D. Sokolova. Micol. Phytopathol. 2, 71-79 (2015) In Russ.

12. I.G. Vorob'eva, Ecological niches of pathogenic micromycetes in West Siberia: diss. abstr. (Novosibirsk, 2011) In Russ.

13. E.Yu Toropova, V.V. Piskarev, V.Yu. Sukhomlinov, Agrochem. 11, 57-62 (2019a) In Russ.

14. O.A. Kazakova, E.Yu. Toropova, I.G. Vorob'eva, AIC of Russia 23, 931-934 (2016) In Russ.

15. E.Yu Toropova, I.G. Vorob'eva, M.A. Mustafina, M.P. Selyuk, Agrochem. 5, 76-82 (2019b) In Russ.

16. N.A. Kuptsevich, I.N. Porsev, E.Yu. Tiropova, Bulletin of Altai SAU 12, 15-19 (2014) In Russ.

17. E.Yu. Lazareva, O.A. Kazakova. Poly-species insects of forage crops serving as carriers of fungal phytopathogens in Priob'e northern forest-steppe, in Ecological approach to solve problems of integrated plant protection: Proceedings of International conference of Siberian scientific school on plant protection, Novosibirsk (2019) In Russ.

18. A. Hajihassani, Z.T Maafi, A. Hosseininejad, J. Pl. Diseas. Prot. 120, 77-84 (2013) 